Khairunnisa. et al. Pembinaan Masyarakat Sebagai Aplikasi Masyarakat Cerdas...

\title{
PEMBINAAN MASYARAKAT SEBAGAI APLIKASI GERAKAN MASYARAKAT CERDAS MENGGUNAKAN OBAT (GeMa CerMat)
}

\author{
Khairunnisa $^{1}$, Embun Suci Nasution ${ }^{1}$ \\ ${ }^{1}$ Departemen Farmakologi Farmasi, Fakultas Farmasi, Universitas Sumatera Utara \\ Corresponding: khairunnisa7@usu.ac.id, nisa152@yahoo.com
}

\begin{abstract}
ABSTRAK
Masalah penggunaan obat tidak rasional merupakan masalah yang menjadi perhatian besar oleh Kementerian Kesehatan Indonesia. Pada masyarakat seringkali dijumpai berbagai masalah dalam penggunaan obat, misalnya penggunaan obat bebas secara tidak tepat dan kurangnya pemahaman tentang cara menggunakan, cara menyimpan dan membuang obat-obatan secara tidak tepat. Hal ini disebabkan masih kurangnya pemahaman masyarakat dan perilaku yang salah dalam penggunaan obat. Oleh karena itu, untuk meningkatkan pemahaman masyrakat dalam penggunaan obat perlu dilakukan edukasi kepada masyarakat mengenai pemilihan obat dan penggunaan obat yang rasional melalui pelatihan yang merupakan bagian dari Gerakan Masyarakat Cerdas Menggunakan Obat (GeMaCerMat).

Pelatihan GeMaCerMat ini menggunakan metode Cara Belajar Ibu Aktif (CBIA). Metode ini sesuai digunakan untuk melakukan edukasi tentang penggunaan obat rasional terutama dalam penggunaan obat swamedikasi dan metode ini kami tawarkan dalam kegiatan pengabdian ini.Hal ini karena sasaran dari pengabdian ini merupakan ibu rumah tangga yang mempunyai peranan penting untuk mengambil keputusan dalam penggunaan obat di keluarga. Metode CBIA ini dibagi dalam 3 tahapan: kegiatan I dan II dilakukan dalam kelompok, dan kegiatan III dilakukan secara individual di rumah dan dievaluasi dalam pertemuan berikutnya.

Hasil dari kegiatan pengabdian masyarakat ini sangat membantu dan dapat memberikan manfaat yang baik kepada masyarakat karena kegiatan ini dapat memberikan dampak yang cukup besar terhadap kesehatan masyarakat. Kegiatan pengabdian ini terbukti mampu meningkatkan persepsi dan pemahaman masyarakat terhadap penggunaan obat-obatan secara rasional terutama obat-obatan yang diguna sebagai pengobatan swamedikasi. Metode kegiatan CBIA sebagai metode pembelajaran kepada masyarakat banyak digunakan dan sangat efektif sebagai metode edukasi kesehatan kepada masyarakat.
\end{abstract}

Kata kunci: Penggunaan Obat Rasional, GeMa CerMat, CBIA

\begin{abstract}
The problem of irrational drug use is a matter of great concern by the Ministry of Health of Indonesia. In the community there are often many problems with drug use, such as the inappropriate use of over-the-counter medicines and lack of understanding about how to use, store and dispose of drugs inappropriately. This is due to the lack of public understanding and wrong behavior in drug use. Therefore, to improve people's understanding of the use of drugs, it is necessary to educate the public about drug selection and rational use of drugs through training that is part of Smart Community Movement Using Drugs (GeMaCerMat).

This GeMaCerMat training uses the method of Active Mother Learning (CBIA). This method is suitable for educating the use of rational drugs, especially in the use of self-medication and this method has been offered in this service. This is because the target of this dedication is housewife who has an important role to take decision in the use of drugs in the family. The CBIA method is divided into 3 stages: activity I and II are conducted in groups, and activitiys III are conducted individually at home and evaluated in subsequent meetings.

The results of community service activities are very helpful and can provide good benefits to the community because these activities can have a significant impact on public health. This devotional activity proved able to improve people's perception and understanding of rational use of
\end{abstract}


Khairunnisa. et al. Pembinaan Masyarakat Sebagai Aplikasi Masyarakat Cerdas...

drugs, especially drugs used as self-medication treatment. CBIA method of activity as a method of learning to the community is widely used and very effective as a method of health education to the public.

\section{PENDAHULUAN}

Penggunaan obat yang rasional adalah bila pasien menerima obat yang sesuai dengan kebutuhan klinis, dosis yang sesuai, dengan waktu yang adekuat dengan biaya yang terendah bagi pasien da masyarakat. Penggunaan obat yang tidak rasional merupakan masalah besar di seluruh dunia. Berdasarkan data dari WHO lebih dari $50 \%$ obat-obatan yang diresepkan, diserahkan atau dijual tidak rasional, dan setengah dari seluruh pasien gagal mendapatkan obatobatan yang sesuai untuk mereka (WHO, 2014).

Beberapa contoh dari penggunaan obat yang tidak rasional adalah: penggunaan obat yang terlalu banyak (polifarmasi), penggunaan antibiotik yang tidak tepat, dosis yang tidak mencukupi, penggunaan obat-obat injeksi yang berlebihan ketika penggunaan obat-obatan oral lebih tepat, penggunaan pengobatan sendiri (swamedikasi) yang tidak tepat dan ketidakpatuhan terhadap regimen pengobatan (WHO, 2014).

Masalah penggunaan obat tidak rasional ini menjadi perhatian penting oleh WHO dan pemerintah Indonesia. Hal ini dikarenakan dampak yang ditimbulkan cukup besar dalam penurunan mutu pelayanan kesehatan dan peningkatan anggaran pemerintah yang dialokasikan untuk obatobatan (Kemenkes RI, 2012). Faktor-faktor yang penyebab terjadinya penggunaan obat yang tidak rasional antara lain: kurangnya informasi, kesalahan dan kurangnya pendidikan dan latihan bagi tenaga kesehatan, kurangnya komunikasi tenaga kesehatan dengan pasien, kurangnya fasilitas, diagnosis yang tidak tepat, permintaan pasien, tidak efektifnya regulasi obat, aktivitas promosi dari industri farmasi yang berlebihan (Ambwani, S dan Mathur AK, 2006).

Untuk mengatasi hal diatas pemerintah Indonesia dalam hal ini Kementerian Kesehatan Indonesia mengajak seluruh elemen praktisi kesehatan (rumah sakit, Puskesmas, pusat-pusat Kesehatan, dokter dan apoteker), perguruan tinggi serta organisasi kemasyarakatan untuk berperan aktif dalam peningkatan penggunaan obat secara rasional. Pemerintah telah melaksanakan berbagai kegiatan baik pelatihan ataupun kampanye tentang penggunaan obat secara rasional dan pemerintah mencanangkan Gerakan Masyarakat Cerdas Menggunakan Obat (GeMaCerMat). Gerakan ini merupakan upaya bersama antara pemerintah dan masyarakat melalui rangkaian kegiatan dalam rangka mewujudkan kepedulian, kesadaran, pemahaman dan keterampilan masyarakat dalam menggunakan obat secara tepat dan benar.

\section{ANALISIS SITUASI}

Di Sumatera Utara praktik penggunaan swamedikasi juga cukup tinggi walaupun tidak ada data yang akurat mengenai itu. Penyakit-penyakit yang biasa diobati menggunakan pengobatan swamedikasi merupakan penyakit-penyakit yang cukup ringan seperti batuk, sakit kepala, demam dan sebagainya. Berdasarkan data Riskesdas 2013, di Sumatera Utara sebanyak lebih dari $30 \%$ rumah tangga menyimpan obat untuk kegunaan swamedikasi di rumah, dimana berdasarkan jenis obat $85 \%$ nya merupakan obat kerasdan $87 \%$ merupakan antibiotik. Berdasarkan karakteristik antara rumah tangga perkotaan dan pedesaan tidak menunjukan perbedaan dalam jumlah penyimpanan obat-obatan yang akan digunakan dalam swamedikasi dan jenis obat yang disimpan. Hal ini menunjukan penggunaan obat terutama untuk pengobatan swamedikasi tidak digunakan secara rasional. Banyak faktor yang mungkin menyebabkan hal ini terjadi antara lain kurangnya informasi yang berasal dari sumber yang tepat seperti dokter dan apoteker, banyaknya iklan masyarakat yang terdapat ditelevisi, radio dan poster yang tidak memenuhi syarat sehingga dapat menyebabkan kekeliruan dalam masyarakat, selain itu kebiasaan dan sosial budaya masyarakat juga mempengaruhi keputusan dalam penggunaan obat-obatan. Oleh karena itu, diperlukan edukasi kepada masyarakat tentang penggunaan obat secara rasional terutama untuk pengobatan swamedikasi. 
Khairunnisa. et al. Pembinaan Masyarakat Sebagai Aplikasi Masyarakat Cerdas...

Dua mitra kelompok masyarakat terlibat dalam pengabdian masyarakat ini. Mitra pertama adalah Kelompok pengajian Ibu-Ibu Aisyiyah di daerah Medan Polonia secara geografis masih merupakan daerah di tengah Kota Medan. Walaupun daerah tersebut merupakan daerah kota Medan, tapi mayoritas penduduknya berekonomi menengah ke bawah dan berpendidikan sekolah menengah. Kelompok pengajian Ibuibu Aisyiyah di daerah Medan polonia ini cukup banyak anggotanya. Mitra kedua adalah ibu-ibu perwiridan di daerah Gaperta yaitu Perwiridan As-Syakinah. Mitra kedua ini juga berada di daerah Kota Medan, dianggotai oleh masyarakat di daerah Gaperta. Anggota perwiridan ini mempunyai tingkat pendidikan yang bervariasi.

\section{METODE PELAKSANAAN}

Kegiatan pengabdian ini merupakan kegiatan pelatihan GEMA CERMAT dengan metode yang digunakan adalah metode CBIA (Cara Belajar Ibu Aktif). Metode ini merupakan kegiatan pelatihan pemberdayaan masyarakat yang melibatkan ibu-ibu rumah tangga untuk aktif dalam berbagai kegiatan termasuk mencari informasi dalam penggunaan obat pengobatan swamedikasi untuk kegunaan rumah tangga. Metode CBIA telah diujicoba dan hasilnya memuaskan serta dapat merubah perilaku masyarakat terutama dalam pengobatan sendiri. Metode CBIA ini langsung dapat dirasakan dalam perubahan pola konsumsi obat di rumah tangga sehingga pemakaian obat tidak diduplikasi dengan beberapa nama dagang obat yang ternyata isinya persis sama (Kemenkes RI, 2012).

\section{Mitra Pengabdian}

Dalam pengabdian ini kami melibatkan 2 kelompok ibu-ibu pengajian. Setiap kelompok ibu pengajian dibagi lagi kepada 5 kelompok kecil, yang setiap kelompok terdiri dalam 8 orang, masingmasing kelompok menunjuk ketua kelompok.

\section{Mitra Pengabdian Pertama (1)}

Mitra pertama (1) dalam kegiatan ini merupakan kelompok ibu-ibu pengajian Aisyiyah di daerah Kelurahan Sari Rejo, Medan Polonia. Kelurahan Sari Rejo walaupun secara geografis merupakan daerah Kota Medan tetapi masyarakat disana banyak yang mempunyai taraf kehidupan menengah ke bawah dan berpendidikan sekolah menengah. Kelompok pengajian Ibu-ibu Aisyiyah di daerah Sari Rejo Medan Polonia mempunyai anggota yang cukup banyak dan banyak terlibat dalam kegiatan sosial baik dalam bidang kesehatan maupun ekonomi masyarakat di daerah tersebut. Kegiatan pengabdian pada mitra pertama ini dilakukan di sebuah Mesjid Taqwa Ikhwanu shofa Jln Cinta Karya No. 8, Sari Rejo, Medan Polonia. Kegiatan pengabdian ini diikuti oleh 34 orang anggota kelompok pengajian tersebut.

\section{Mitra Pengabdian Kedua (2)}

Mitra Pengabdian kedua (2) dalam pengabdian ini adalah kelompok ibu-ibu pengajian/Perwiridan As-Syakinah di Kompleks Kodam, Gaperta. Kegiatan pengabdian pada mitra kedua ini pertemuan pertama dilakukan di rumah salah satu anggota perwiridan dan pertemua kedua akan dilakukan di mushola di komplek tersebut. Kegiatan pengabdian di mitra pengabdian kedua ini diikuti oleh 42 orang anggota kelompok pengajian/perwiridan tersebut.

\section{Prosedur Kegiatan}

Kegiatan ini dilakukan dalam 2 kali kunjungan setiap mitra. Sebelum dilakukan kegiatan pelatihan dengan metode CBIA, dilakukan kegiatan pendahuluan. Kegiatan pendahuluan ini berupa kegiatan seminar atau edukasi dengan beberapa materi inti, yaitu: jenis obat untuk swamedikasi, informasi obat pada kemasan dan brosur, cara pemilihan dan mendapatkan obat untuk swamedikasi, bentuk sedian obat dan cara menggunakannya, efek samping obat, serta cara penyimpanan obat. Kegiatan ini dilakukan pada pertemuan pertama.

Metode CBIA ini dibagi dalam 3 tahapan: kegiatan I dan II dilakukan dalam kelompok, dan kegiatan III dilakukan secara individual di rumah. Kegiatan I dan II membutuhkan waktu 4-5 jam, tergantung dari dinamika kelompok. Kegiatan I dilakukan setelah kegiatan pendahuluan, dan Kegiatan II dan III dilakukan pada pertemuan kedua. 
Khairunnisa. et al. Pembinaan Masyarakat Sebagai Aplikasi Masyarakat Cerdas...

\section{HASIL PELAKSANAAN}

\section{Persiapan Modul dan Paparan Pelatihan \\ Sebelum dilakukan kegiatan pembinaan} masyarakat mengenai penggunaan obat rasional dalam swamedikasi dan cerdas dalam menggunakan obat, tim pelaksana kegiatan terlebih dahulu mempersiapkan modul yang akan digunakan dalam pelatihan tersebut. Dalam hal ini modul yang digunakan adalah modul yang telah disiapkan oleh Kementerian Kesehatan Republik Indonesia untuk kegiatan pembinaan masyarakat cerdas menggunakan obat atau GeMa CerMat

Modul pelatihan ini terdiri dari 2 buku yang berjudul "Penggolongan Obat" dan "Cara Penggunaan Obat". Modul tersebut mengandung materi-materi penting dalam mengenalkan masyarakat mengenai obat dan cara menggunakan obat secara cerdas dan rasional. Selain itu juga menyiapkan bahan presentasi yang akan dipaparkan kepada masyarakat untuk lebih menambah pengetahuan masyarakat mengenai obat, kandungan paparan itu terdiri dari materi Jenis obat, Informasi obat pada kemasan dan brosur, Cara pemilihan dan mendapatkan obat, Bentuk sedian obat dan cara menggunakannya, Efek samping obat, Cara penyimpanan obat.

Modul berupa buku dan paparan ini diperbanyak dan dibagikan kepada masyarakat yang turut serta dalam kegiatan pengabdian ini, sehingga nantinya bisa menjadi rujukan mereka untuk meyebarluaskan informasi yang telah mereka peroleh kepada keluarga dan masyarakat disekitarnya.

\section{Pelatihan Kegiatan Gerakan Masyarakat Cerdas Menggunakan Obat}

Kegiatan Pengabdian GeMa CerMat ini menggunakan metode CBIA (Cara Belajar Insan Aktif). Metode ini merupakan kegiatan pelatihan pemberdayaan masyarakat yang melibatkan masyarakat untuk aktif dalam berbagai kegiatan termasuk mencari informasi dalam penggunaan obat pengobatan swamedikasi untuk kegunaan rumah tangga. Metode CBIA telah diujicoba dan hasilnya memuaskan serta dapat merubah perilaku masyarakat terutama dalam pengobatan sendiri. Metode CBIA ini langsung dapat dirasakan dalam perubahan pola konsumsi obat di masyarakat sehingga pemakaian obat tidak diduplikasi dengan beberapa nama dagang obat yang ternyata isinya persis sama (Kemenkes RI, 2012).

Kegiatan pengabdian ini terdiri dari 3 tahapan kegiatan yang dilakukan dalam 2 kali pertemuan, Kegiatan pertama pemaparan yang berjudul "Gema Cermat (Gerakan Masyarakat Cerdas Menggunakan Obat), kegiatan kedua merupakan kegiatan kelompok yaitu mengenal obat-obatan dengan cara melihat informasi yang terdapat dalam kemasan seperti bahan aktif, dosis, efek samping, indikasi, cara penggunaan, cara penyimpanan dan kontraindikasi. dan kegiatan ketiga merupakan kegiatan mandiri yaitu dengan melakukan kegiatan mencari informasi obat-obatan yang terdapat di rumah, dimana obat-obatan yang dirumah dibawa ke tempat dilakukannya pelatihan dan dilakukan identifikasi.

Sebelum dilakukan kegiatan pelatihan dengan metode CBIA, dilakukan kegiatan pendahuluan. Kegiatan pendahuluan ini berupa kegiatan seminar atau edukasi dengan beberapa materi inti, yaitu: Jenis obat untuk swamedikasi, Informasi obat pada kemasan dan brosur, Cara pemilihan dan mendapatkan obat untuk swamedikasi, Bentuk sedian obat dan cara menggunakannya, Efek samping obat, Cara penyimpanan obat.

Metode CBIA ini dibagi dalam 3 tahapan: Kegiatan I dan II dilakukan dalam kelompok, dan kegiatan III dilakukan secara individual. Kegiatan I dan II memakan waktu $4-5$ jam.

\section{Tahapan-tahapan Metode CBIA:}

1. Kegiatan I (kelompok)

Kepada masing-masing kelompok diberikan 1 (satu) paket obat yang terdiri dari bermacam-macam jenis obat yang berasal dari 4 jenis penyakit yaitu obat untuk mengatasi demam, diare, gangguan pencernaan, flu dan batuk. Setiap penyakit terdiri dari 8-10 jenis obat dengan merek dagang yang berbeda-beda dan bentuk sediaan yang berbeda. Masingmasing peserta didalam kelompok diminta untuk mengamati kemasan obat untuk melihat nama dagang, dan nama bahan aktif yang terdapat dalam kemasan obat tersebut, kemudian mengkelompokan obat berdasarkan 
Khairunnisa. et al. Pembinaan Masyarakat Sebagai Aplikasi Masyarakat Cerdas...

jenis bahan aktifnya, bukan indikasi penggunaan obat. Kegiatan ini dilakukan untuk memaparkan ke masyarakat tentang bahan aktif yang terdapat dalam sedian obat yang terdapat di pasaran.

\section{Kegiatan II (Kelompok)}

Tahap kegiatan ini bertujuan agar peserta berlatih mencari informasi dari kemasan, dengan cara meneliti setiap tulisan yang tercantum dalam kemasan maupun brosur. Tahap ini merupakan kegiatan untuk mengumpulkan informasi yang diperlukan sebagai dasar melakukan pengobatan swamedikasi, menggunakan lembar kerja yang telah disediakan, masing-masing peserta menulis untuk dirinya sendiri.

Informasi yang harus dikumpulkan, yaitu: Nama bahan aktif, Indikasi, Aturan penggunaan, Efek samping, Kontraindikasi, Interaksi obat.

\section{Kegiatan III (Individual)}

Melakukan pengamatan terhadap obat yang sering digunakan untuk keluarga di rumah, lalu melakukan pencatatan seperti yang dilakukan pada kegiatan II. Kemudian setelah itu di diskusikan

\section{Evaluasi Hasil Pelatihan Penggunaan Obat Rasional}

Evaluasi dilakukan untuk mengetahui pengaruh kegiatan pelatihan ini terhadap persepsi dan pengetahuan peserta mengenai pengobatan obat rasional dalam swamedikasi. Kegiatan ini mendapati bahwa setelah dilakukan pelatihan sebagai bentuk intervensi untuk meningkatkan pemahaman dan pengetahuan peserta dalam hal ini ibu rumah tangga terdapat perubahan pengetahuan dan persepsi peserta mengenai penggunaan obat rasional terutama penggunaan obat untuk swamedikasi, bagaimana penyimpanan, pembuangan dan mengenal obat-obatan yang rusak.

Setelah dilakukan intervensi berupa pelatihan penggunaan obat rasional, peserta semakin mengetahui mengenai penggolongan obat-obatan terutama obat-obatan yang dapat digunakan sebagai obat yang dapat digunakan dalam swamedikasi. Setelah dilakukan intervensi terjadi peningkatan responden yang telah mengetahui defenisi dari swamedikasi yaitu $85,7 \%$ responden mengetahui bahwa mengobati penyakit yang menggunakan obat yang dibeli tanpa resep dokter adalah swamedikasi dari $60,3 \%$ sebelum dilakukannya intervensi.

Hasil analisa juga mendapati bahwa terjadi sedikit peningkatan pengetahuan mengenai tidak semua obat dapat diberi tanpa resep dokter dari hanya 46,2 \% responden mengetahui menjadi 48,2 \% responden. Terjadi peningkatan jumlah responden yang mengetahui dan menyadari bahwa obat yang dibeli tanpa resep dokter tidak boleh diminum lebih dari 7 hari berturut-turut dari $60,3 \%$ menjadi $78,6 \%$.

Responden juga semakin mengetahui dan menyadari bahwa obat-obatan yang mereka peroleh harus disimpan dengan baik untuk menjaga kualitas dari obat tersebut. Terjadi peningkatan pengetahuan mengenai penyimpanan obat, setelah dilakukan intervensi sebanyak 85, $7 \%$ responden mengetahui bahwa obat harus disimpan jauh dari sinar matahari dan $89,3 \%$ responden menyadari bahwa obat jangan disimpan pada tempat yang lembab terutama dalam bentuk sediaan tablet dan kapsul sehingga obat tersebut tidak dapat digunakan lagi. Mengenai tanda atau ciri obat yang rusak juga terjadi peningkatan dari $67,9 \%$ responden menjadi 92,9 \% responden mengetahui bahwa obat yang telah mengalami perubahan warna, bau dan rasa tidak dapat digunakan lagi.

Keberhasilan intervensi juga dapat dilihat dengan semakin meningkatkan jumlah responden yang mengetahui cara pembuangan atau pemusnahan obat yang tidak digunakan lagi atau kadaluarsa. Sebelum dilakukan intervensi hanya 25,6 \% yang mengetahui bahwa obat tersebut tidak boleh hanya dibuang ditempat sampah, Setelah dilakukan intervensi $41,1 \%$ responden mengatakan obat yang tidak digunakan lagi atau kadaluarsa tidak boleh langsung dibuang ke tempat sampah.

Informasi obat, terutama obat yang digunakan untuk pengobatan swamedikasi selain dapat diperoleh dari petugas kesehatan yang berada di apotek juga dapat dilakukan dengan cara mendapatkan informasi mengenai kegunaan, dosis obat dan efek samping melalui brosur obat. Setelah dilakukan intervensi, responden semakin menyadari bahwa informasi mengenai indikasi obat, dosis obat dan efek samping 
Khairunnisa. et al. Pembinaan Masyarakat Sebagai Aplikasi Masyarakat Cerdas...

dapat diperoleh melalui brosur obat $(92.9 \%)$ dari $66,7 \%$ responden sebelum dilakukannya intervensi.

Peningkatan pengetahuan juga terjadi dimana hampir semua responden telah mengetahui bahwa obat yang mempunyai tanda lingkaran hijau merupan obat bebas dan obat yang bertanda lingkaran berwarna biru merupakan obat bebas terbatas yang dapat diperoleh tanpa resep dokter. Peningkatan pengetahuan ini cukup signifikan, sebelum dilakukan intervensi hanya $23,1 \%$ responden yang mengetahui bahwa obat dengan tanda lingkaran berwarna hijau pada kemasan merupakan obat bebas, dan hanya $24,4 \%$ responden atau peserta pelatihan mengetahui bahwa obat dengan tanda lingkaran berwarna biru merupakan obat yang dapat diperoleh tanpa resep dokter.

\section{Evaluasi Kegiatan Pengabdian}

Evaluasi hasil kegiatan ini adalah: Peserta yang terlibat dalam kegiatan pengabdiaan ini menyambut baik kegiatan seperti ini dan berharap kegiatan seperti ini dapat dilakukan secara terus menerus untuk meningkatkan pengetahuan penggunaan obat yang selama ini tidak mereka ketahui. Banyak pengetahuan yang mereka peroleh ketika dilakukan kegiatan seperti ini sehingga mereka sekarang mulai menyadari dan mengetahui cara pemilihan, penyimpanan, penggunaan serta pemusnahan obat yang baik sesuai dengan ketentuan.

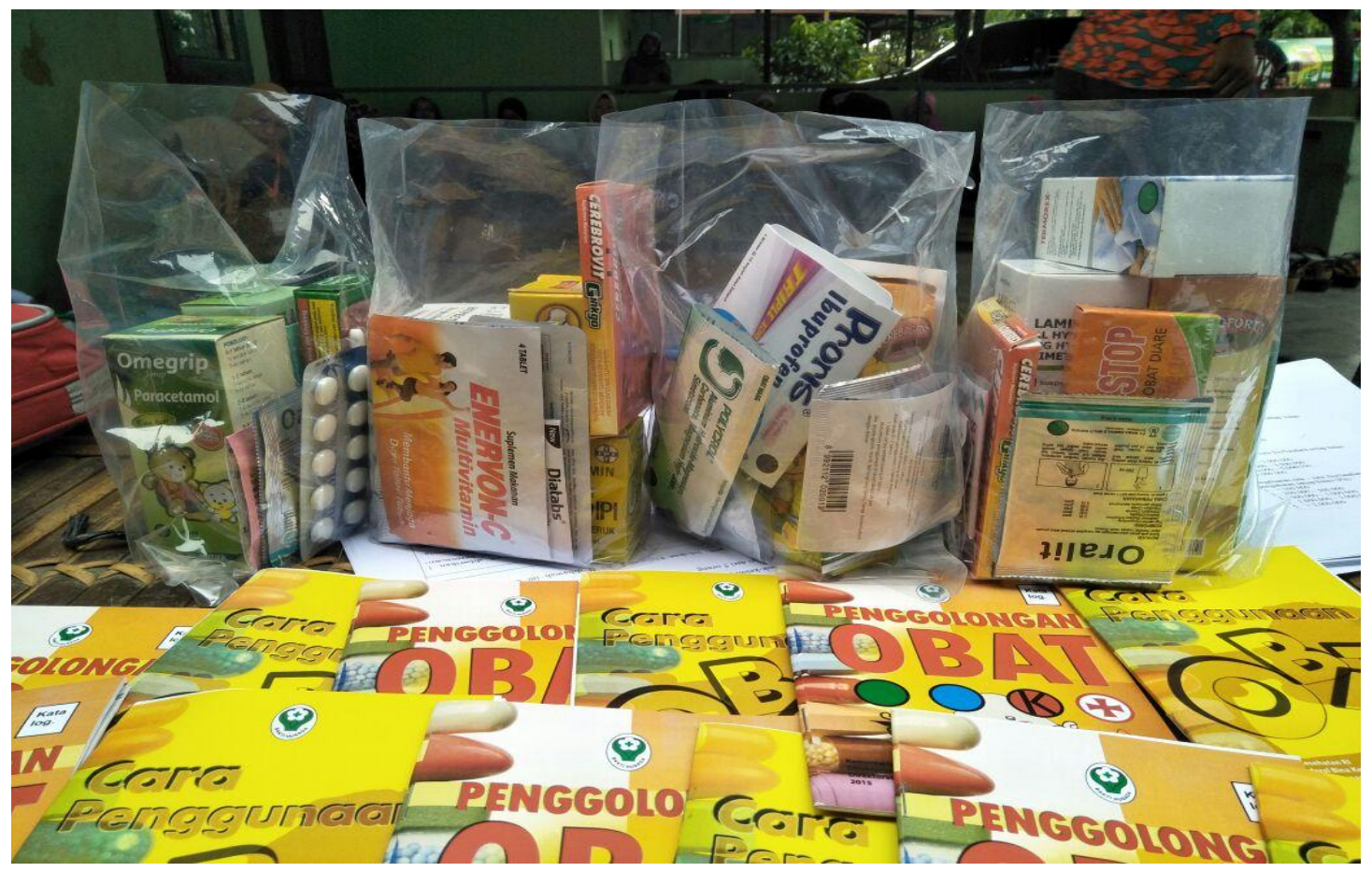

Gambar 1 : Sebagian perlengkapan pengabdian 
Khairunnisa. et al. Pembinaan Masyarakat Sebagai Aplikasi Masyarakat Cerdas...
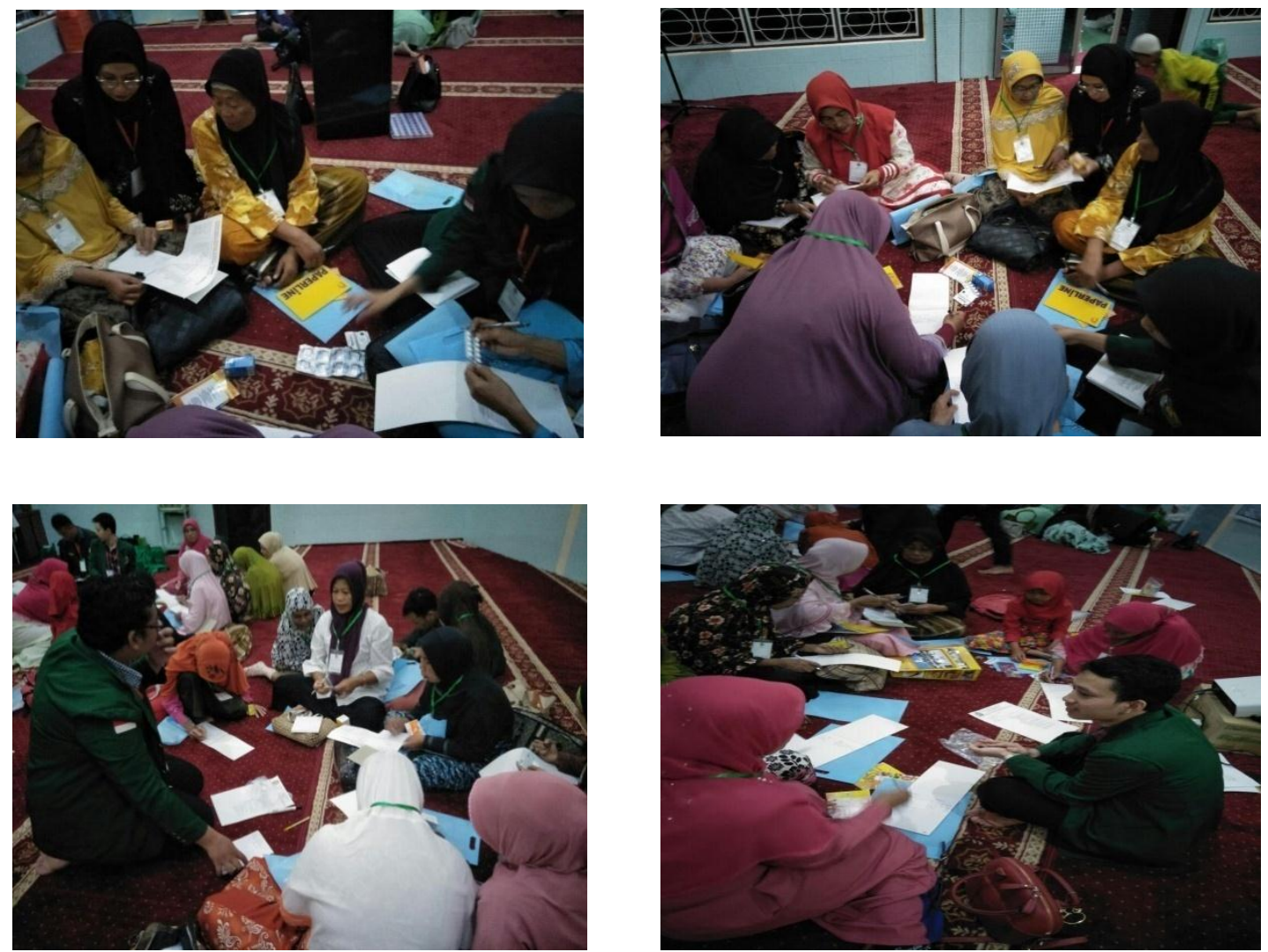

Gambar 2: Kegiatan Pengabdian di Mitra 1
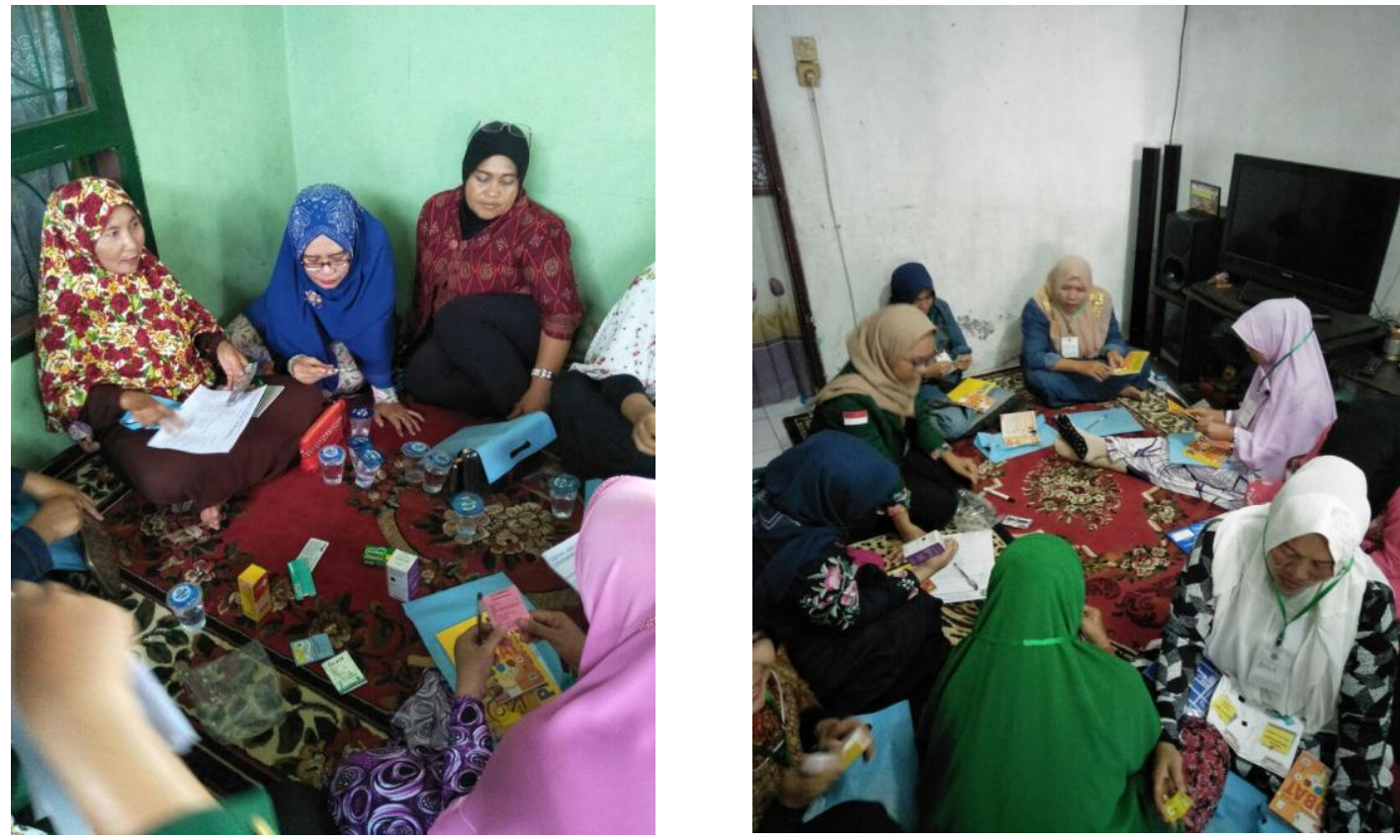

Gambar 3 : Kegiatan Pengabdian di Mitra 2 
Khairunnisa. et al. Pembinaan Masyarakat Sebagai Aplikasi Masyarakat Cerdas...
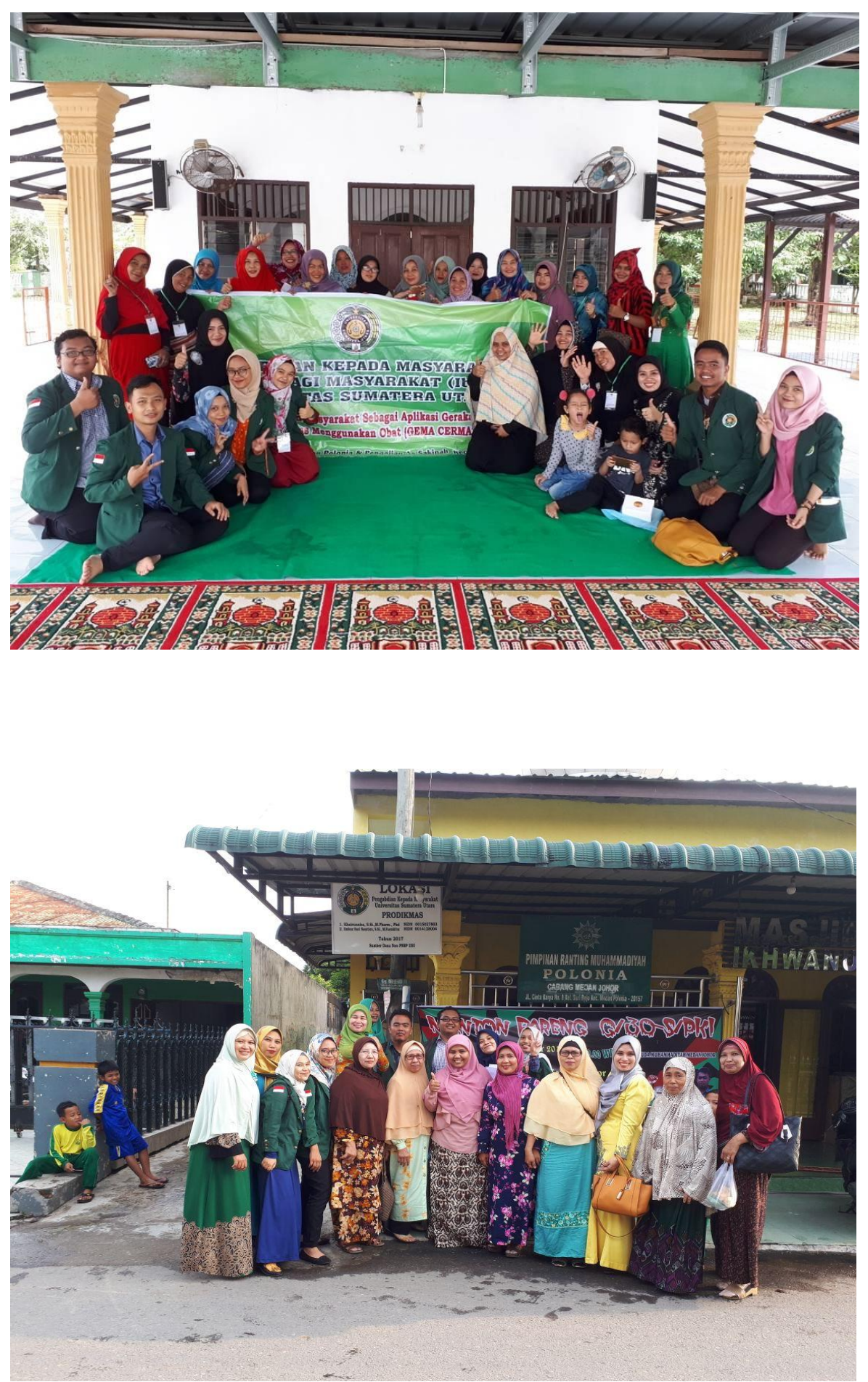

Gambar 4 : Berfoto bersama dengan sebagian peserta pelatihan 
Khairunnisa. et al. Pembinaan Masyarakat Sebagai Aplikasi Masyarakat Cerdas...

\section{UCAPAN TERIMA KASIH}

Artikel ini merupakan hasil dari Program Pengabdian kepada Masyarakat yang sumber danannya dari BPPTN Universitas Sumatera Utara Sesuai dengan Surat Perjanjian Penugasan Pelaksanaan Pengabdian kepada Masyarakat Program Mono Tahun (Dosen Muda)Tahun Anggaran 2017Nomor:3224/UN5.2.3.2.1/ PPM/2017, Tanggal 24 Juni 2017. Oleh karena itu, kami mengucapkan terima kasih kepada Rektor Universitas Sumatera Utara atas dukungan dana dan fasilitas yang diberikan. Dan kami juga mengucapkan terima kasih kepada Lembaga Pengabdian Pada Masyarakat Universitas Sumatera Utara yang telah memberikan kesempatan kepada kami untuk melaksanakan program pengabdian ini. Dan terima kasih juga kepada Mitra pada kegiatan pengabdian ini.

\section{KESIMPULAN}

Berdasarkan hasil kegiatan pengabdian yang dilakukan dapat diambil kesimpulan bahwa kegiatan pengabdian masyarakat ini sangat membantu dan dapat memberikan manfaat yang baik kepada masyarakat karena kegiatan ini dapat memberikan dampak yang cukup besar terhadap kesehatan masyarakat. Kegiatan pengabdian ini terbukti mampu meningkatkan persepsi dan pemahaman masyarakat terhadap penggunaan obatobatan secara cerdas terutama obat-obatan yang dibeli secara bebas. Kegiatan pelatihan Gema Cermat dengan mengunakan metode CBIA sebagai metode pembelajaran kepada masyarakat banyak digunakan dan sangat efektif sebagai metode edukasi kesehatan kepada masyarakat.

\section{DAFTAR PUSTAKA}

Ambwani,S., Mathur, A.K. (2006). Rational Drug Use. Health Administrator. XIX:1: 5-7

Direktorat Bina Penggunaan Obat Rasional.(2008). Materi Pelatihan Peningkatan Pengetahuan Dan Keterampilan Memilih Obat Bagi Tenaga Kesehatan.Jakarta: Direktorat Bina Penggunaan Obat Rasional
Kemenkes RI. (2012). Pergerakan Penggunaan Obat Rasional. Jakarta: Kementerian Kesehatan Republik Indonesia.

Kementerian Kesehatan RI. (2014). Riset Kesehatan Dasar 2013.(Online).http://depkes.go.id/downloa ds/riskesdas2013/Hasil\%20Riskesdas\%20 2013.pdf. Diakses tanggal 15 Juli 2017.

Oelva Dianawati, Fasich, dan Umi Athijah. (2008). Hubungan Persepsi Terhadap Iklan Di Televisi Dengan Perilaku Swamedikasi Pelajar SMU Negeri Di Surabaya.Majalah Farmasi Airlangga.Vol.6 No.1, hal: 10-16.

WHO.(2014). Rational use of Medicine. http://www.who.int/medicines/areas/ration al_use/en/ diakses tanggal 15 Juli 2017.

Kemenkes RI. (2017). Materi Promosi Gema Cermat. Jakarta: Kementerian Kesehatan Republik Indonesia. http://binfar.kemkes.go.id/2016/05/materipromosi-gema-cermat-1-logo-bannerbrosur-poster-dan-stiker diakses tanggal 10 Juli 2017 